\title{
WOMEN'S POLITICAL PARTICIPATIONS IN EAST KALIMANTAN
}

\author{
Ida Wahyuni Iskandar
}

State Administration Science, Faculty of Social and Political Sciences, Universitas Mulawarman, Indonesia

\begin{abstract}
The struggle of women to actualize themselves in the political arena is very difficult since the situation that always accompanies is even an obstacle for them to move freely. Meanwhile, political reform which occurred in Indonesia has certainly given great opportunity to women to participate. In this study, the sampling technique is purposive sampling. The analysis technique used in this study is using interactive model analysis. The results of the research are vote casting the most basic of political participation which women are already involved in general election to vote for governor of East Kalimantan. They have realized that their vote determines the future of their region. For this the simplest form of political participation, most of the women in East Kalimantan have performed their right. The role of the participation of women activists is important in inviting women in East Kalimantan to participate in general elections. To increase activist women's participation is not only the responsibility of one party. Political education for women needs to be held more widely, not only for certain groups. Efforts to increase women's participation in politics certainly need systemic collaboration from various parties from the government, political parties, and community organizations.
\end{abstract}

Keyword : Women's, Political Participation, East Kalimantan

\section{INTRODUCTION}

Nowadays, democracy is facing numerous challenges: escalating political inequality, the widespread declining political participation, voter's incompetence, etc. (Parvin \& Saunders, 2018). Democracy recognizes the citizens' rights to negotiate with governing bodies through voting, campaigning, candidacy, and occupying political office and/or performing individual or collective lobbying (Vissandjee et al., 2005). Such a democratic system enables individuals to enjoy an equal ability to have an influence on the political agenda, whether it is direct or indirect via representatives, and to express their concerns conveyed into wider decision-making processes and the establishment of policy.

Democracy embodies the desire that decisions which affect the whole society must be taken into account by all its members. Each member must have the same rights in the process of these decision making. Nevertheless, the intensity of the development of the existence of humanity in women in general is not optimal. Albeit the political equality is formally guaranteed, women around the world encounter the inequality in politics whether they are in elected office, bureaucratic posts, or everyday political participation (Palaniswamy, Parthasarathy \& Rao, 2019; Chowdhury, 2009; Hara, Trihartono \& Viartasiwi, 2018). This is clearly implied by the strong tradition of most community members who discredit women by regarding women as second persons. Meanwhile, women have an interest to take part in politics in order to determine the direction of policy in shaping a regional regulation or occupying strategic positions, such as members of Regional Representative Council, governors, mayors, regents and other strategic positions. Female leaders in the community sometimes have doubts about their capacity which ultimately becomes less acceptable to the broader community. In fact, in democratic system, women are regarded no more as a political object. Therefore, many political parties accept the fact that woman is actually an attractive personal figure and able to play a role in public space.

Inclining women's representation in politics, especially in general elections, does not occur instantly; rather, it is the long and ongoing struggle to realize the right of everyone to achieve equality and justice. One of these efforts is through the realization of legislation which has alignments and affirmations towards increasing women's representation. The Chairperson of the East Kalimantan Women's Solidarity Forum (Forsop), Priskilla Evalianita Randabunga revealed that women's involvement in politics is still minimal because there is a constraint to the access for women. All political domains are mostly dominated by male politicians. This also relates to the stigma that women tend to be weak. In fact, women's participation in politics can influence policies especially those related to gender issue. It is also expected to be able to influence policies regarding the issues that have often been considered to gain less concerns by men, such as the issue of domestic violence, including violence against women and children. With their presence in the political realm, women can determine policies to cover 
these problems (kaltim.tribunnews.com).

The data from the results of the National Social Economic Survey (Susenas) in September 2018 released by BPS (Indonesian Statistics Agency) of East Kalimantan revealed that there is a gender gap in the participation of meeting activities in the residential area which is quite high between men and women. The percentage of male population participating in activities meetings were much higher than that of women $(32.5 \%$ compared to $12.5 \%$ ). The finding confirms that the

The word participation comes from Latin, namely "participatio" which means taking part. The word "participatio" comes from the verb "participare" which contains the meaning of participating, so that participation contains the meaning of taking part or participating.According to the formal research that political participation may be defined as "those activities of citizens that attempt to influence the structure of government, the selection of government authorities, or the policies of government" (Conway, 2011).

One of important aspects of democracy is political participation since democracy largely depends on the active participation of citizens in various governance activities, ranging from voting in elections, donating to political campaigns to protesting and running for office (Leigh, 2018). Political participation is an integral part of democracy system. The right of political participation is an essential feature in a democratic dispensation (Chuku, 2009).

According to most view, political development patrilineal culture which is adopted by the people of East Kalimantan still strongly exists. In such a culture, men are considered more entitled to play a role in decision making and more people are encouraged to participate in the meeting activities. This culture also influences women's political participation, including in political meetings or discussions.

\section{LITERATUR REVIEW \\ A. Political Participation}

does involve some degree of expanded popular participations, yet it is crucial to differentiate among the conditions of such expansion. Historically, in the Western countries, the dimension of political development is closely associated with the widening of suffrage and the induction of the population new element into the political process. This mass participation process means a decision-making diffusion, and participation brings some influences on decision and choice. However, in several new states, mass participation has not been paired with an electoral process. Yet, it has been a new essential form of mass responses to elite manipulation. It should be regarded that even such a limited participation exhibits a function to play in nation building since it represents a means of creation new loyalties and a new feeling of national identity (Finkle \& Gable, 1966).

Table 2.1 Forms of political participation Almond and Verba version

\begin{tabular}{|c|ll|}
\hline Conventional & \multicolumn{2}{|c|}{ Non-Conventional } \\
\hline 1. Voting & 1. Submission of petitions & \\
2. Political Discussion & 2. Demonstrate or protest & \\
3. Campaign activities & 3. Confrontation & \\
4. Establish and join & 4. Strike & \\
interest groups & 5.Acts of political violence against property \\
5. Individual communication & (destruction, burning, bombing) & \\
with political and & 6.Actions of political violence against humans \\
administrative officials & (kidnapping, murder) & \\
& 7. Guerrilla warfare & \\
& & \\
\end{tabular}


One of the most common differences between various types of political participation is conventional vis a vis unconventional (Stockemer, 2014). Previously, since 1970s, several study on political participation have often distinguished the political actions of conventional and

serves as the need of publicizing information or views related to the public concern issue.

On the other hand, the the form of conventional participation is by far normally lawful and more structured, e.g. a political party membership, lobbying, voting, contacting political officials, campaigning, attending political meetings, etc. In this context, therefore, one refers to kinds of participation which are intrinsically embedded in the accepted institutional politics boundaries. In this respect, such activities may be called "formal" (Henn \& Foard 2012).

\section{B. Women's political participations}

The women's involvement in the political world is affirmative action to provide them the widest opportunity. Based on this argument, it is believed that the advancement of women into the public sphere and occupying strategic spaces of decision making is the only way for their interests to be represented. The involvement of women in policy making will be able to bring Indonesian people to a system of gender justice and make good governance (Sofiyah, 2012). Generally, gender equality advocates and feminists believe that representation of women will inform the significance of a more peaceful, cooperative, and focused policy on the family's, children's, and women's welfare (Hara, Trihartono \& Viartasiwi, 2018). Perceptions regarding candidates and officeholders from women generally conform to stereotyped assumptions about issue positions as well. Women are thought to be more interested in, and more effective when dealing with particular issues, such as education, child care, healthcare, poverty, womens' issues, and the environment, rather than are their counterparts.

There are at least four obstacles for women in unconventional types which depends on the praxis qualitative attributes. As shown in the table above, a specific praxis can be qualified as an act of participation in politics when it serves the concept of "telos" in the process of decision-making or, at least it

participating in the political field, which is caused by:

1) Women play two roles at once, namely reproductive roles and productive roles, both inside and outside the home;

2) Women have relatively low education compared to men because of the different opportunities they get;

3) There are cultural additions related to the sexual division of labor and patterns of interaction between women and men that limit women's movements;

4) There are legal barriers for women such as the prohibition of land ownership, the prohibition of participating in education or family planning programs without the consent of her husband or father (Mukarom, 2018).

\section{General Election}

Election is the process of electing people to occupy particular political positions. These positions are diverse, ranging from the president, representatives of the people in different levels of government to the chief of village. Election is conceptually a means of implementing people's sovereignty. Through elections the legitimacy of people's power is implemented through the surrender of a portion of their power and rights to their representatives in parliament and government (Jurdi, 2018).

The cornerstone of representative democracy is elections. In an election, citizens are enabled to select their representatives in the political system through their votes (Galais \& Blais, 2017). Democracy means that citizens choose their political leaders from among opposing candidates 
in regular elections. This implies that most citizens should be willing to participate, that there are real choices to be made, and that these choices make a difference in the policies that are implemented by the government (Engel, 1999).

Then the general election is an important means for the community to elect people's representatives as stated by Reynold (Basri 2012: 131), "General Election is a method in which the votes obtained in the election are translated into seats won in parliament by parties and candidates. General elections are an important means for selecting people who will work on their behalf in the state policy-making process".

\section{RESEARCH METHODOLOGY}

In line with the problems and objectives of the study, the researchers used a qualitative research approach with the type of descriptive research. The type of data collected in this study can be divided into two namely secondary data and primary data. Source of data in this study focuses on human sources, events and documentation. In this study the sampling technique used was purposive sampling. The main data collection techniques in this study are interviews, observation and documentation. The analysis technique used in this study is to use interactive model analysis (Saldana et.al, 2014).

\section{RESULTS AND DISCUSSION}

\section{A. Vote casting participation}

The modest level of participation is to be able to vote, which is, to have the right for voting, being in a position to go to the urns on voting days, and having access to documents which will inform people's choice (Berges, 2015). Individuals who do nothave interest in politics often start out voting. In this sense, it is possible that individuals begin with conventional activities which do not divert considerable resources and time (Stockemer, 2014). Likewise, voting in this study is the most accessible form of participation by the women activists. All the activists who became informants always voted in the East Kalimantan regional elections in $2008-2018$.
Women religious organizations are one of the most important institutions which can influence the women political perspective in general. Based on data from the National Socio-Economic Survey (Susenas), conducted in September 2018 by BPS (Indonesia Statistics Agency) of East Kalimantan, the most member-having organizations were engaged in the religious sector $(40.52 \%)$ and the social sector $(21.43 \%)$. Meanwhile, the areas of the least attended organizational activity by the population were the economic, political and environmental sectors with a percentage of $2.62 \%$, $3.51 \%$, and $3.52 \%$, respectively. Similarly, the conditions were also found when classified according to the area ofresidence. The urban population who participated in the activities of religious and social organizations were $37.88 \%$ and $19.41 \%$ respectively. Meanwhile, the inhabitants in rural areas was $46.67 \%$ involved in religious activities, and $26.14 \%$ in social sector. Religious organizations were mostly followed by the people of East Kalimantan in both urban and rural areas since these organizations can play an important role to encourage their members to participate in politics at least by casting vote in elections.

Women's religious organizations invite their members to participate in politics, at least through voting. Activists are aware of the importance of voting in the elections. Voting is an important part of democracy. One vote from voters can determine who will become the leader of East Kalimantan in the next five years. Elected leaders will influence the future of East Kalimantan. In addition to personal awareness, the organization where they are active in activities also supports the use of voting rights in the elections.

Women's political participation in voting in the East Kalimantan Province is not significantly different from that of men. The total number of voters reached 2,349,862 as sets by the General Election Commission of East Kalimantan Province, consisting of 1,274,932 male voters and 1,074,932 female voters. (Central Statistics Agency, 2009). In 2013, the governor election 
experienced an increase in the number of voters to $2,794,297$ consisting of $1,478,885$ male voters and $1,315,412$ female voters. In the governor election 2018 , there were $2,439,438$ voters consisting of 1,263,257 male voters and 1,176,181 female voters (General Election Commission of East Kalimantan Province).

Indonesia is a country with a Muslim majority population. There is important consideration of choosing a prospective Muslim leader for some of the population of Indonesia, including the regional head election. Likewise, there are East Kalimantan activists who also have religious considerations and even make it as the first prerequisite, that elected governor in the East Kalimantan PILKADA must be a Muslim. Some activists also consider prospective leaders who care about the local issues the community organization fights for. Caucus Women and NAPAS activists who fight for women's rights including political participation prefer to choose women supporting candidates for regional heads. Hence, they will implement the policies which pay attention to the welfare of women and families. In addition to the organization's activists, women activists from other fields also have the same consideration that the leaders must understand the women's expectations and conditions. The criteria of leaders who have a preference for women are also considered by one of the disability activists in East Kalimantan.

\section{B. Political campaigns}

The successful team strives to collaborate with community organizations in seeking mass or campaign participants. Even, an impartial community organization still encourages its members to participate in the regional election. For religious organizations, for example, Aisyiah did not officially announce to support one of the governor candidates.

However, if there is a personal invitation for the socialization event from the candidate governor, the members of the organization are allowed to attend. In addition, to campaigns held by supporting parties, there are also activists who can also be involved in campaigns in their respective organizations or communities. For example, it happens when they attend an event. This phenomenon was revealed by one of the East Kalimantan Muslim NU administrators. In addition, if there is an activity, it can also provide an opportunity for the regional head candicate to introduce him/herself and convey the vision and mission. This campaign activity certainly can save campaign costs for the candidates for regional heads.

In addition to being a campaign participant, there were also activists who became campaign committees. Usually activists who are active as administrators of political parties will be open for campaign committee. They are looking for the masses to join the campaign. One indicator is that usually used to judge whether a campaign is successful or not is the number of masses coming to the campaign of regional head candidates. Open campaigns have more opportunities in gathering more mass which results in the number of citizens or the community knowing the explanation of the vision and mission which results in the formation of people's perceptions of candidates. The role of activists who can gather the masses is very important in the campaign. In addition, the women's campaign committee also usually takes care of consumption, especially for VIPs.

The East Kalimantan Women's Empowerment and Child Protection Agency also gave a message to regional women to exercise their right to vote and pay attention to the vision and mission of the candidate governor's mission delivered during the campaign. In addition, women are also expected to share their aspirations in the campaign. However, unfortunately the East Kalimantan Women's Empowerment and Child Protection Agency does not monitor whether women really convey their aspirations during the campaign. As the time goes, the introduction of vision and mission is also not only through direct campaigns. Providing political participations and carrying out political campaigns are not only applicable for the public; statesmen 
can also easily carry out their works through social media. The election activities of the parties, election campaigns announcements and all kinds of actions for the public are presented on social media accounts. (Dasli, 2019).

In 2018, it was found that in East Kalimantan, men were using the internet relatively more frequently than women. However, the difference between the two was insignificant, both for the rural and urban areas. The number of men accessing the internet in East Kalimantan was as much as $59.46 \%$, slightly different with women reaching $56.83 \%$. It proved that women also needed to access information as much as their counterparts. Based on the results of the September 2018 National Socio-Economic Survey (Susenas) released by the National Statistics Agency of East Kalimantan, the reason the most individuals in East Kalimantan accessed the internet was to have social media $(45.59 \%)$, to get news/information $(39,57 \%)$ and entertainment (38.09\%).

Based on the data above, the internet, social media in particular, can be a potential and effective campaign tool. Moreover, many people in East Kalimantan use the internet. Therefore, political campaigns through social media can be an option in order that more people recognize the candidates and their vision, mission and programs. In addition, social media is also relatively inexpensive; thus, campaign costs can be more effective than printed media/tools, such as brochures, etc.

\section{Political discussions}

For female activitsts involved in politics, formal political discussions held by regional head candidates or political parties are still rare. Rather, only a minority of Indonesian women have ever become 'active citizens' in democratic parlance since they have not gained the opportunity to be involved in public politics. It is also because the women have been convinced to think that politics is masculine (Blackburn, 1999). As such, it is not surprising that the success team of regional head candidates is still dominated by men and it still very lacks opportunity for women to be involved in political discussions to formulate the policies of prospective regional heads.

The form of participation of formal political discussion is still considered to be limited to certain groups, for example people who are active in supporting parties for the regional head candidates. Political discussions about policies which will be brought by the regional head candidates are still limited to certain groups. Formal political discussion about policy has not involved the general public. Policy discussions are still internally limited to political parties. Initiatives from the general public are also difficult to access so there needs to be an initiative of regional head candidates or political parties. Therefore, as admitted by Mrs. B, a disability activist, who stated that she only encountered informal political discussions such as discussions with friends, rather than attending formal political discussions held by parties or regional head candidates.

The importance of political discussion for women in the family environment was also expressed by Mrs. F, a tourism activist. According to her, women's opinions can influence other family members. If women have opinions and issue aspirations for family members, father and children can follow. This happens in the family environment. One of the managers of the East Kalimantan Women's Caucus said that there had actually been women's concern for politics. They observed and criticized candidates for regional heads with friends. However, sometimes they did not realize that this activity is also a form of political participation. They still feel anti-politics.

\section{The Importance of Women's Political Participation}

Women's participation in addition to politics is also evident from the many women's organizations that actively carry out activities in various fields. Women are involved in development through activities in various organizations that they participate in relating to religion, health, education 
and others. With the participation of women, it is hoped that it can improve the quality of families including their children. Indonesian women asserted that it was essential that women participate in politics in order that woman's issues, people's welfare, and the nation's living standards, become matters of concern. Women have specific needs which can only be understood by themselves, for instance, issues of reproductive health, children's education, children's well-being, family welfare, and household chores.' (Graham Davies, 2005). Women are very important to participate in politics to fight for women's rights. Of course, women who understand their rights more. In addition, family rights, especially for children that are better understood by women, are also important to fight for.

\section{E. Enhancing women's political participations}

One of the efforts to increase women's participation in politics is through political education. Political education for women can be carried out by various parties such as the government, political parties, and community organizations. Governments and related authorities may accelerate education for critical political participation which is linked to critical historical awareness as politically undesirable. Citizens 'competence in critical thinking, turns out to be of key importance for strengthening the learner citizens' position, their participation in their own education as citizens and their own perspectives as participating political subjects (Hedtke \& Zimenkova, 2013). Political education is important to improve critical thinking so that women can actively participate in politics.

One of the political education programs for women from the government is conducted by the Office of Women's Empowerment and Child Protection. Reducing political inequality for women is one of the Ministry's priority programs for empowering women and children. The program was supported by the Office of Women's Empowerment and Child Protection in the areas including East Kalimantan. It is also a priority program for regions with various activities.

"Nationally, our Ministry program is actually backing up with our program activities in the area. We have a $3 \mathrm{~N}$ program named. so, three must end. That's what we always say. That is what we always back up with program activities in the regions to become priority programs in the region. So, the $3 \mathrm{~N}$ is ending violence against women, ending trafficking, ending women's economic disparities and ending the political gap for women. Three of them. So, the $3 \mathrm{~N}$ is what we are, a national program that we back up in the area. So that is all we are concerned with, with the vision of the governor's mission being our official priority program through the $3 \mathrm{~N}$ program." (Mrs. M, East Kalimantan Women's Empowerment and Child Protection Agency, 25 January 2019). Efforts to increase women's participation are also carried out by the government through training programs which are held every year. This training invites political parties, beginner voters, and community institutions. Various materials were delivered such as how to campaign, determine the issues brought during the election to count votes.

Political parties as the main stakeholders related to the women's political participation should have a clear agendas to achieve the ideal condition of women's representation in political field from the level of caderization, recruitment, political education for woman, that have a clear impact both on the quality and quantity on the woman politicians (Purwanti, 2015). The socialization of political education held by the government was felt to be lacking. There are still many people who do not understand political education. Political parties must also play a role in efforts to increase women's political participation through various programs, one of which is political education. In addition, the party also has an obligation to provide political education. However, the function of this party has not been effective. Human resource constraints in the party are one reason. Collaboration between political parties and the government is needed to be able to increase political education especially for women. 


\section{CONCLUSION}

Women's political participation in East Kalimantan is generally still limited to voting. In addition, many of them are also able to participate in the political campaign because they tend to have more free time and are easy to be invited with the community. Women's involvement can increase the mass so that the campaign looks crowded. However, there still lack opportunities to convey thoughts in campaigns for women. Likewise, there is also lack of access for women to political participation which influences policies that will be carried out by regional heads, for example through political discussion and contacting. It is also widespread that women perceive that political arena is dirty and attributed to men only. This leads to misconception that women are not suitable to jump into politics. Hence, they hesitate to be involved into practical politics, such as having roles in political parties for the strategic positions, decision making process, etc. The other explanations for minimum women's participation in politics is related to culture of patriarchy which still has strong influence in East Kalimantan, in particular, and Indonesia in general. In addition, it is also found that passive women's political involvement is reasoned by several theories underlying the people's motives.

\section{REFERENCE}

Basri Seta (2012), Introduction to Political Science, Jogjakarta: Indie Book Corner Berges, S. (2015). Is Motherhood Compatible with Political Participation? Sophie de Grouchy's Care-Based Republicanism. Ethical Theory \& Moral Practice, 18(1), 47-60.

Blackburn, S. (1999). Women and Citizenship in Indonesia. Australian Journal of Political Science, $34(2)$, 189-204. doi:10.1080/10361149950362 Conway, M. (2001). Women and Political Participation. Political Science and Politics, Vol. 34, No. 2 (Jun., 2001), pp. 231-233.
Chuku, G. (2009). Igbo women and political participation in Nigeria, 1800s-2005. The International journal of African historical studies, 42(1), 81-103.

Dasli, Y. (2019). Use of Social Media as a Tool for Political Communication in the Field of Politics. Sosyal Bilimler Arastirmalari Dergisi, 9(1), 244-251.

Engel, M. (1999). State \& local government: Fundamentals \& perspectives. Peter Lang Pub Incorporated.

Finkle, J. L., \& Gable, R. W. (1966). Political development and social change (No. HM33 F5).

Graham Davies, S. (2005). Women in politics in Indonesia in the decade post-Beijing. International Social Science Journal, 57(184), 231-242.

Galais, C., \& Blais, A. (2017). Duty to Vote and Political Support in Asia. International Journal of Public Opinion Research, 29(4), 631.

Hara A.E, Trihartono A., \& Viartasiwi N. (2018). Democracy and Continuing Marginalization of Women in Indonesian Politics. E3S Web of Conferences, Vol 73, p 11005 (2018), 11005.

Henn, M., \& Foard, N. (2012). Young people, political participation and trust in Britain. Parliamentary affairs, 65(1), 47-67.

Hedtke, R., \& Zimenkova, T. (Eds.). (2013). Education for civic and political participation: A critical approach (Vol. 92). Routledge.

Jurdi, F. (2018). Introduction to General Election Law. Jakarta: Kencana.

Leigh, B. T. (2018). The Impact of Country Characteristics on Civic Knowledge and Political Participation. Politikon, 37, 6.

Miles, M. B., Huberman, A. M., \& Johnny Saldana, J. (2014). Qualitative data analysis.

Sage.

Mukarom, Z. (2008). Women and Politics: Study of Political Communication on Women's Representation in the Legislature. 
MediaTor (Jurnal Komunikasi), 9(2), 257-270.

Palaniswamy, N., Parthasarathy, R., \& Rao, V. (2019). Unheard voices: The challenge of inducing women's civic speech. World Development, 115, 64-77.

Parvin, P., \& Saunders, B. (2018). The Ethics of Political Participation: Engagement and Democracy in the 21st Century. Res Publica (13564765), 24(1), 3-8.

Purwanti, A. (2015, April). Quota Laws for Women in Politics: Implementation in Indonesia.

In Conference Proceedings, Kuala Lumpur International Business, Economics and Law Conference (Vol. 6, No. 4, pp. 18-19).

Sofiyah, S. L. (2012). Women's Participation and Representation as an Effort for Democratization in Indonesia. EGALITA.

Stockemer, D. (2014). What drives unconventional political participation? A two-level study. The Social Science Journal, 51, 201-211.

Vissandjee, B., Apale, A., Wieringa, S., Abdool, S., \& Dupéré, S. (2005). Empowerment beyond numbers: Substantiating women's political participation. Journal of International Women's Studies, 7(2), 123-141. 